\title{
Neighboring Countries' Press Coverage of the Syrian Refugee Crisis: An Analytical Study of Lebanese "Ya-Sour", Jordanian "Al-Wakeel News" and Turkish "Turk Press"
}

\author{
Hatem Alsridi* $^{*}$ Abdul-Karim Ziani \\ Dep. Of Mass Communication, University of Bahrain, P.O. Box 32038, Kingdom of Bahrain
}

\begin{abstract}
Local and international media, in their various traditional and digital forms, have shed considerable light on the Syrian refugee crisis caused by the war that has engulfed their country since 2011 . The nature and objectives of press coverage varied from one media to another, and from country to country, some of which were linked to political agendas (Zaaroor, 2018, Maharat Foundation, 2016), and others were linked to emotional and humanitarian factors (Alhayek, 2014). Syrian refugees were portrayed in different media settings (Ramasubramanian et al., 2018). The image of refugees in the Western press also differed from country to another (Berry et al., 2015, Efe, 2019). This crisis continues and so is the press coverage with considerable variation in attitudes and trends.This study aims to analyze how the most prominent news websites in neighboring countries i.e. Jordan, Lebanon and Turkey have covered the Syrian refugee crisis, by showing the interest of the Lebanese "Ya-sour", Jordanian "Al-Wakeel News" and Turkish "Turk Press" websites in the issues of the refugees, their complications, the highlighted aspects, and the position of these sites on the Syrian refugee crisis through the topics they focused on and the issues they prioritized.The study showed that the most important topics discussed were "security", "economy" and "politics" and the main focus was on "refugee impact on commodity prices", "difficult living conditions for refugees" and "refugee impact on the labour market". As for persuasion methods, it has been found that the "provocative" and "violent" methods were the most used in the examined press coverage.
\end{abstract}

Keywords: Syrian Refugees, News Websites, Media discourse, Content analysis

DOI: $10.7176 / \mathrm{NMMC} / 80-05$

Publication date:May $31^{\text {st }} 2019$

\section{Introduction}

Press coverage of the Syrian refugee crisis in neighboring countries (Turkey, Jordan and Lebanon), and also in Europe and the rest of the world has been the subject of many Arab and foreign studies and research. Using different theories and research methods, they sought to study, and analyze patterns and methods of media coverage and monitor trends of opinion on this crisis.

One of these studies is that of Greenwood et al. (2019) who analyzed 811 images, depicting migration from Turkey to Europe in 2015. The results showed that photographers overwhelmingly highlighted the way the migrants' were crossing, their weakness and differences, minimizing any attempt to portray the interconnections or integrations that were happening.

The report of the UN High Commissioner for Refugees (Berry et al., 2015) described how the press of five European countries: Britain, Germany, Italy, Spain and Sweden covered the refugee and migrant crisis between 2014 and 2015. The study focused on the following questions: (1) What are the main sources of press coverage? (2) What are the most mentioned political parties? (3) Where are refugees and migrants coming from? (4) What terms are used to describe who is trying to join the EU? (5) What topics are most covered? (6) What are the justifications provided by persons trying to join the European Union? (7) What are the proposed solutions to the crisis of refugees and migrants in coverage? The report showed a difference between countries in the sources of journalists, language used, justifications and solutions to the refugee crisis. The study also showed a difference in the level of subjects covered in the press coverage. The "humanitarian" topics were more present in the Italian coverage than in the British, German or Spanish newspapers. Threats such as welfare or cultural threats were the most prevalent in Italy, Spain and Britain. Overall, the report found that the Swedish press was the most positive towards refugees and migrants, while coverage in the UK was the most negative and polarized.

In a study on the representation of Syrian refugees in the British press (Venir, 2015), a sample of four newspapers: "The Telegraph", "The Guardian", "The Mirror" and "The Sun" showed that the negative image of Syrian refugees is quantitatively marginal. According to the study, this positive representation was found by focusing on the innocence and vulnerability of Syrian refugees by referring to the moral responsibility of the United Kingdom in helping the Syrians by portraying the Syrians as real refugees in contrast to other "opportunistic" migrants, and individual refugees with tragic stories.

Using Framing Theory as a theoretical reference, a comparative study (Ramasubramanian et al., 2018) on how the media discourse in both Arabic and English of the geopolitics of the Syrian refugee crisis framed four 
basic frameworks: (1) "borders", (2) "institutions", (3) "victim" and (4) "war". The study also showed that the Arab articles, which focused on the crisis from an emotional and humanitarian frames, indicate that these humanitarian frames can act as symbolic resistance to the ways in which the dominant external forces have influenced the region. In contrast, frames from English sources represent refugees as victims, citing their inability to face the obstacles they face in seeking asylum.

Hoyer (2016) in her research on the framing of Spanish newspapers ("El Mundo", "El Pais", and "ABC") of the Syrian refugee crisis, touched on the impact of the choice of words on Spanish public opinion and the possibility of creating a kind of division between the refugee and the host country. The use of terms such as "personas" creates a stronger sense of identity and empathy by readers, while terms such as "judgments de asilo" create a sense of division and abstraction of refugees from humanity. She adds that this sense of identity and division not only affects attitudes towards the acceptance of refugees but also the ways these refugees are treated when they arrive in Spain or other countries.

A study on the analysis of the representations of Syrian asylum seekers in the Turkish press between March 2011, when the first Syrians arrived in Turkey, and December 2015, the end of the project (Efe, 2019) showed two main findings (1) The volume of humanitarian discourse and assistance related to the Syrian impact on Turkey is higher in the research sample. (2) The discourse on the impact of Syrian refugees in Turkey is often accompanied by a security and economic threat, and therefore Syrian asylum seekers pose a potential threat to the security, cultural integrity and economy of the country. In a similar study of Syrian refugees (Yaylaci et al., 2015) that analyzed the content of three Turkish newspapers ("Hurriet", "Yeni Safak", and "Gumhuriyet"), it appears that the political trend of the newspapers and their attitudes towards the Turkish government strongly influences the formation of news concerning Syrian refugees. It added that the formation of news about the Syrians, Ezzidis and Kobanis cannot be discussed independently of the war in Syria, its social and humanitarian repercussions, and the way these effects are reflected on the different political groups in Turkey, and on the different perceptions of Turkey's foreign policy. Thus, it can be emphasized that individuals who wish to obtain information about Syrians, Ezzidis and Kobanis through the newspapers (the sample of the study) can access sound information by reading and evaluating all three newspaper reports together.

Alhayek (2014) examined the crisis of Syrian refugee women by analyzing their campaign speech on Facebook, "Refugee Not Captives". The study showed that the portrayal of Syrian refugees through the media on the Internet is done through a complex process of Orientalist representation and self-orientation. Dominant representations also discourage the voices of disadvantaged refugee women and women activists who stress the complexity and diversity of refugee women's experiences.

In another study on how the Greek, German and British press addressed the issue of the refugee crisis in Europe (Fotopoulos et al., 2016), it was found that the media had taken a unified approach to cover this crisis, which contrasts with the conflicting views of European leaders. At the same time, the study notes that the hate speech drew media attention and caused public concern. The study also said that refugees were portrayed as victims of the civil war in Syria, helpless and desperate, while there was a focus among all the newspapers on the "numbers" of the crisis.

At the Arab level, the results of a master's thesis (Zaaroor, 2018) on the factors governing the coverage of the Syrian issue by the Lebanese newspapers through an analysis of four Lebanese newspapers in 2015 ("AsSafir", "Annahar", "Alakhbar" and "Almustaqbal"), showed that the political and professional factors that contribute to coverage differ from one newspaper to another and vary depending on each newspaper. The other factors combined are consistent in their handling of the issue in all newspapers. A study of the size and quality of media coverage in Lebanon, Jordan, Egypt and Morocco on issues of asylum and displacement (Maharat Foundation, 2016), showed that media coverage of refugee issues, particularly Syrians, was influenced by two main factors: (1) the size of asylum and proximity, and (2) The media coverage of refugee issues and its links to political positions. While these correlations were consistent with government positions in Jordan, they formed a tool for political conflict in Lebanon, where there was a clear political engagement between political officials on issues related to individual development plans and fear of resettlement and its reflection on demographic balances. Syrian asylum in Egypt has been used as a propaganda tool in campaigning.

Al-Mazahrah (2016) discussed the Jordanian press coverage of the Syrian refugee crisis in Jordan, the topics covered in this crisis, and the patterns used to cover the issues related to it through "Al-Rai", "Al-Dustor", and "Al-arab Alyoum" newspapers. The results of the study indicate that the Jordanian newspapers are less interested in covering the Syrian refugee crisis in Jordan, as well as restricting the use of press patterns in presenting the crisis to news and news reports.

In a master's thesis on the issues of Syrian refugees presented on Jordanian state television and the private channel "Ro'ya", the results showed that the most frequent subjects from the point of view of the staff in the news sector based on (Mhirat, 2014), are in the following order (1) political, (2) Social and (3) economic. As for the press templates used, the "news" template was the most frequently used for both channels.

In a study on the coverage of the Jordanian daily newspapers of the Syrian events between 2011 and 2013 
(Farej et al., 2014), the researchers confirmed Lipman's (1992) view that the public responds more to the world image they place in their minds than real - world events.

\section{Theoretical Framework}

The theoretical framework of the study depends on two basic theories that will help to frame and understand how the news websites of neighboring countries presented and covered the Syrian refugee crisis. (1) The Agenda Setting, in which McCombs (1972) sees news media as a powerful force for setting an agenda aiming to focus public attention on a few key public issues. This will be utilized in this study with a number of major and subcategories in the content analysis form, among which are: subject category, persuasion methods category, structural elements, journalistic styles, content trends. The main question of the study is how the news websites, the sample of the study, covered the Syrian refugee crisis and the extent to which these news websites tried to put their media agenda on the content and coverage of Syrian refugee issues. (2) Gatekeeping Theory, which is seen in the media and communication sciences as a comprehensive process through which the social reality of the media is constructed (Barzilai-Nahon, 2009). It will be used to find out the topics covered by the news websites on content and issues of Syrian refugees, and the source of the press coverage of the refugee cases on which the news sites depend.

\section{Research Questions}

RQ 1: What are the structural elements and journalistic styles, and what is the nature of the subjects, their source and location in the publication of the news websites?

$\mathrm{H}$ 1: There are statistically significant differences at 0.05 between the structural elements and the press patterns in the press coverage of the Syrian refugee crisis within the sample news websites.

$\mathrm{H}$ 2: There are statistically significant differences at 0.05 between the nature of the subjects and their source and location in the publication in the press coverage of the Syrian refugee crisis within the news websites.

RQ 2: What are the focal personalities of press coverage? What is the description of the Syrian refugee? What are the expected risks or the proposed solutions to the Syrian refugee crisis?

$\mathrm{H}$ 1: There are statistically significant differences at 0.05 among the focal figures, and between the elements of the characterization of the Syrian refugee in the press coverage of the Syrian refugee crisis within the news sites.

H 2: There are statistically significant differences at 0.05 between the expected risks or the proposed solutions to the Syrian refugee crisis.

RQ 3: What are the content trends, the persuasion methods, and persuasive methods used in press coverage?

$\mathrm{H} \mathrm{1}$ : There are statistically significant differences at 0.05 between the content trends in the press coverage of the Syrian refugee crisis within the news websites.

$\mathrm{H} 2$ : There are statistically significant differences at 0.05 between persuasion methods and persuasive methods in the press coverage of the Syrian refugee crisis within the news sites.

\section{Methodology}

The study is part of the descriptive approach and is one of the surveying studies that focus on the content survey using the content analysis tool. It is a set of methodologies through which the concepts included in the content as well as the relationships between these concepts are discovered through systematic quantitative and qualitative research on the characteristics of this content. On this basis, we will use this method to analyze the content of the issues related to the press treatment of the Syrian refugee crisis, using frequency and percentages to represent the results statistically. We will also determine the coefficient of consistency between these results.

\subsection{Population and sample of the study}

The study population is limited to a sample of Arabic-language news websites in neighboring countries hosting Syrian refugees. It includes the most popular news websites in Jordan, Lebanon and Turkey according to Alexa, a website ranking specialist. The Jordanian "Al-Wakeel News" website, which was launched on December 15 , 2012, was ranked third in Jordan and ranked fourth in the ranking of international websites used in Jordan (Alexa, 2019). The website "Ya-Sour" was launched on November 1, 2005, ranked first among Lebanese websites, and ranked sixth in the international websites used in Lebanon (Alexa, 2019). The Turkish news website "Turk Press" launched on June 1, 2014, is the first Arabic-language Turkish news website in Turkey (Alexa, 2019).

\subsection{Selection of topics and content}

The selected group comprises all the topics published in the three news websites on the Syrian refugee crisis from March 1, 2014 to the date the US President declared "Victory on Daesh (ISIS) and the restoration of Syrian territory" on 1 March 2019. These articles include 1869 news stories, 84 news reports, 39 investigative news reports and 32 press interviews. 


\subsection{Selection of units of analysis}

The units of analysis include registration units and counting units.

First: Registration Units: Content analysis describes content elements quantitatively and qualitatively, which requires the distribution of this content to major and sub-categories to facilitate their study according to the frequency scale of each category. The researchers used the following units to analyze the content of the three news websites in the Syrian refugee crisis: (1) The word unit: This is the basic unit and considered the smallest unit used in the content analysis; the word may refer to a certain symbolic meaning, as may be determined by certain terms or concepts which gives them special meaning. When the word is used as a unit in the analysis of content, the researcher sets up lists of repetitions of selected words or categories in respect of the subject matter analyzed. (2) Subject or idea unit: It is the largest and most important units in the analysis of information materials, and is used to determine values, beliefs and trends.

Second: Counting Units: The counting method was used by researchers to identify and measure the registration units or text units that were previously limited. The most common unit of counting is (1) frequency: It is the most widely used counting unit and has been used to calculate previously challenged registration units. The importance of the subject is evaluated by counting the frequencies. Moreover, despite their similarities, registration units and counting units should not be confused because, while the first identifies the parts of the subject to be analyzed, the latter determines how these parts will be identified. (2) Unit Duration: The use of the unit duration of the count is interesting because it is the factor relied on in the news sites to calculate the time of videos or video graphic accompanying the press article. Registration units were calculated in minutes.

\subsection{Reliability test}

As part of the reliability testing procedures, the researcher analyzed the content of 15 news stories and reports from each news website. This pretest made it possible to test the content analysis form and make the necessary adjustments in order to be as effective a tool as possible to analyze the entire journalistic material of the study sample. As for the measurement of reliability, the value and success of content analysis depends, according to Bernard Berelson, on the categories of analysis used "what was said - how was it said?" (Grawitz, 1993). These categories should be clear and precise and should be based on the main theme of research. We tested $10 \%$ of the journalistic material in the three cases twice by the encoders, the first on August 9, 2018 and again on 20 August 2018. Using the Holsti formula to measure reliability, we obtained an $80 \%$ rate, which would make this result satisfactory (Holsti, 1969). The formula could be represented as follows:

Cf: reliability coefficient

M: Categories agreed upon by encoders (8)

$\mathrm{N} 1+\mathrm{N} 2=$ : The sum of the categories analyzed by the encoders $(10)$

$$
\begin{gathered}
\mathrm{cf}=(\mathrm{N} . \mathrm{M}) /(\mathrm{N} 1+\mathrm{N} 2+\mathrm{Nn}) \\
(2.8) /(10+10)=0.80 \%
\end{gathered}
$$

\section{Results}

The answer to the elements of the first research question: what are the structural elements and the press patterns, what is the nature of the subjects, their source and location in the publication of the news websites? shows the following results where we adopted the methodology for calculating frequencies and percentages as shown in the tables below.

\subsection{Structural elements used with the subjects of the Syrian refugee crisis}

The results indicate that the general trend of the most structural elements used in the subjects of the Syrian refugee crisis in the news websites is "objectivity" which was repeated (1328) times (30.8\%), followed by "personality" (715) times (16.6\%), and then the "links and referrals" element (574) times (13.3\%).

The construction elements differ from one news website to another. The results show that the most structural elements used in the "Al-Wakeel News" website are "objectivity" which was repeated (709) times (45.4\%), followed by "personality" (13.5\%), then "links and referrals" (189) times $(12.1 \%)$. The results show that the most structural elements used in the "Ya-Sour" website were "objectivity" (318) times (25.3\%), followed by "multimedia" 198 times (15.8\%), and in the third place "personality" (184) times (14.6\%). Finally, the "personal" component of the "Turk Press" website came in first place, (321) times (21.4\%,) followed by "objectivity", 301 times (20.1\%) and in the third place "links and referrals" (211) times (14.1\%).

The results indicate that there are statistically significant differences between the three news websites in the structural elements used in the Syrian refugee crisis. The differences in favor of "Al-Wakeel" were as follows: Objective (53.4\%), "slogans" (56.8\%), and "infographic" by (46.2\%). There are also statistically significant differences between the three sites in the construction elements used for "Ya-Sour" in the use of "drawings" and "cartoons" (44.6\%). For the "Turk Press" website, the following elements are represented: "Personality" (44.9\%), "drawings and maps" (46.8\%),"text and hyper media" (59.1\%). In contrast, there are no statistically significant 
differences between the three websites in the following structural elements: "photo gallery", "video graphic ", "links and references", "configuration files", "assembly files".

Table 1. Structural elements used with the themes of the Syrian refugee crisis

\begin{tabular}{|l|l|c|c|c|c|c|c|c|c|c|c|}
\hline \multirow{2}{*}{ No } & Quantitative distribution & \multicolumn{2}{|c|}{ Al-Wakeel } & \multicolumn{2}{c|}{ Ya-Sour } & \multicolumn{2}{c|}{ Turk Press } & \multicolumn{2}{c|}{ Total } & \multicolumn{2}{|c|}{ K2 test } \\
\cline { 3 - 15 } & & $\mathrm{N}$ & $\%$ & $\mathrm{~N}$ & $\%$ & $\mathrm{~N}$ & $\%$ & $\mathrm{~N}$ & $\%$ & Value & Sig \\
\hline 1 & Objectivity & 709 & 53.4 & 318 & 23.9 & 301 & 22.7 & 1328 & 100 & 240.7 & 0.01 \\
\hline 2 & Personality & 210 & 29.4 & 184 & 25.7 & 321 & 44.9 & 715 & 100 & 44.4 & 0.01 \\
\hline 3 & Slogans & 83 & 56.8 & 45 & 30.8 & 18 & 12.3 & 146 & 100 & 43.8 & 0.01 \\
\hline 4 & Drawings \& cartoons & 18 & 19.6 & 41 & 44.6 & 33 & 35.9 & 92 & 100 & 8.9 & 0.01 \\
\hline 5 & Drawings \& maps & 12 & 19.4 & 21 & 33.9 & 29 & 46.8 & 62 & 100 & 7.0 & 0.01 \\
\hline 6 & Photo gallery & 19 & 34.5 & 18 & 32.7 & 18 & 32.7 & 55 & 100 & 0.1 & No Sig \\
\hline 7 & Video graphic & 71 & 32.4 & 61 & 27.9 & 87 & 39.7 & 219 & 100 & 4.7 & No Sig \\
\hline 8 & Multimedia & 112 & 22.0 & 198 & 39.0 & 198 & 39.0 & 508 & 100 & 29.1 & 0.01 \\
\hline 9 & Text and hyper media & 12 & 4.0 & 110 & 36.9 & 176 & 59.1 & 298 & 100 & 137.1 & 0.01 \\
\hline 10 & Links and referrals & 189 & 32.9 & 174 & 30.3 & 211 & 36.8 & 574 & 100 & 3.6 & No Sig \\
\hline 11 & Infographic & 86 & 46.2 & 33 & 17.7 & 67 & 36.0 & 186 & 100 & 23.3 & 0.01 \\
\hline 12 & Configuration files & 18 & 22.8 & 35 & 44.3 & 26 & 32.9 & 79 & 100 & 5.5 & No Sig \\
\hline 13 & Assembly files & 21 & 40.4 & 19 & 36.5 & 12 & 23.1 & 52 & 100 & 2.6 & No Sig \\
\hline
\end{tabular}

\subsection{The press patterns of the news websites that dealt with the refugee crisis}

The results of the study show that most of the press patterns that dealt with the Syrian refugees crisis were: "News stories" which were repeated (1896) times, (74.4\%), followed by the "news report" (499) times (19.6\%), and in the third place "news analysis" (84) times (3.3\%). The general results are consistent with the specific results of each news website, with "News stories" in the first place, followed by "news report" and "news analysis" of all the news websites.

It is clear from the results of the study that there are statistically significant differences between the three websites in dealing with the refugee crisis through the "news report". The differences were in favor of "Ya-Sour" $(41.9 \%)$. The study did not show statistically significant differences between the three websites in the following press patterns: "news stories", "investigative news report", "news Analysis" and "press interview".

Table 2. The press patterns of the news websites that dealt with the refugee crisis

\begin{tabular}{|l|l|c|c|c|c|c|c|c|c|c|c|}
\hline \multirow{2}{*}{ No } & Quantitative distribution & \multicolumn{2}{|c|}{ Al-Wakeel } & \multicolumn{2}{|c|}{ Ya-Sour } & \multicolumn{2}{|c|}{ Turk Press } & \multicolumn{2}{c|}{ Total } & \multicolumn{2}{c|}{ K2 test } \\
\cline { 3 - 14 } & & $\mathrm{N}$ & $\%$ & $\mathrm{~N}$ & $\%$ & $\mathrm{~N}$ & $\%$ & $\mathrm{~N}$ & $\%$ & Value & Sig \\
\hline 1 & News stories & 659 & 34.8 & 617 & 32.5 & 620 & 32.7 & 1896 & 100 & 1.7 & No Sig \\
\hline 2 & News investigative report & 18 & 46.2 & 9 & 23.1 & 12 & 30.8 & 39 & 100 & 3.2 & No Sig \\
\hline 3 & News Analysis & 31 & 36.9 & 28 & 33.3 & 25 & 29.8 & 84 & 100 & 0.6 & No Sig \\
\hline 4 & Press interview & 13 & 40.6 & 8 & 25.0 & 11 & 34.4 & 32 & 100 & 1.2 & No Sig \\
\hline 5 & News report & 189 & 37.9 & 209 & 41.9 & 101 & 20.2 & 499 & 100 & 39.7 & 0.01 \\
\hline
\end{tabular}

\subsection{The nature of the issues related to Syrian refugees}

The results of the study indicate that the most topics related to the issues of Syrian refugees, which were focused on by the news websites are "security topics", which were repeated (885) times $(34.7 \%)$, followed by "economic subjects" (706) 27.7\%), then "political topics" (683) times (26.8\%).

In the same context, "Al-Wakeel News" focused primarily on economic topics (370) times (40.7\%), followed by security issues (309) times (34.0\%), "Political topics" (159) times (17.5\%). The "Ya-Sour" website dealt primarily with "security issues", (401) times (46.0\%), followed by economic subjects, (278) times, (31.9\%), then political subjects (109) times (12.5\%). Finally, the results showed the focus of the "Turk Press" website on "political topics" which were repeated (415) times (54.0\%), followed by security issues (175 times), (22.8\%), and "humanitarian issues" (121) times $(15.7 \%)$. This difference of opinion points to different priorities of neighboring countries that receive Syrian immigrants on their territory.

In the same context, there are statistically significant differences between the three sites in the nature of the issues related to the refugee issue. The differences were in favor of "Al-Wakeel News" (52.4\%). In favor of the "Turk Press" website in the "political issues" by (60.8\%) and "humanitarian issues" $(43.8 \%)$. 
Table 3. The nature of the issues related to Syrian refugees

\begin{tabular}{|l|l|c|c|c|c|c|c|c|c|c|c|}
\hline \multirow{2}{*}{ No } & Quantitative distribution & \multicolumn{2}{|c|}{ Al-Wakeel } & \multicolumn{2}{c|}{ Ya-Sour } & \multicolumn{2}{c|}{ Turk Press } & \multicolumn{2}{|c|}{ Total } & \multicolumn{2}{c|}{ K2 test } \\
\cline { 3 - 11 } & & $\mathrm{N}$ & $\%$ & $\mathrm{~N}$ & $\%$ & $\mathrm{~N}$ & $\%$ & $\mathrm{~N}$ & $\%$ & Value & Sig \\
\hline 1 & Political topics & 159 & 23.3 & 109 & 16.0 & 415 & 60.8 & 683 & 100 & 236.7 & 0.01 \\
\hline 2 & Economic topics & 370 & 52.4 & 278 & 39.4 & 58 & 8.2 & 706 & 100 & 218.4 & 0.01 \\
\hline 3 & Security issues & 309 & 34.9 & 401 & 45.3 & 175 & 19.8 & 885 & $100 \%$ & 87.6 & 0.01 \\
\hline 4 & Human subjects & 72 & 26.1 & 83 & 30.1 & 121 & 43.8 & 276 & 100 & 14.4 & 0.01 \\
\hline
\end{tabular}

\subsection{Sources of the issues of the Syrian refugee crisis}

It is clear from the results of the study that the most sources of the issues of the Syrian refugee crisis in the news websites are the category "more than one source" (553) times (27.2\%), followed by "correspondent" (308) times (15.1\%), then in the third place "politicians" (265) times (13.0\%).

The results showed a difference in the sources of topics according to the news website. The "Al-Wakeel News" website also relied on "social networks, social media" and "refugee affairs in the United Nations" as the source of the subjects, which were repeated 89 times $(10.2 \%)$. The "Ya-Sour" website was ranked second on the "politicians" list, which was repeated 88 times (14.1\%), followed by the source of "social networks and social media" which was repeated 83 times (13.3\%). The "Turk Press" website relied primarily on the source of the "reporter" which was repeated 128 times (23.5\%), followed by "more than one source" (109) times (20.0\%), then "politicians" (98) times (18.0\%).

According to the results of the study, there are significant differences between the three websites in the sources of the issues of the Syrian refugee crisis. The differences were in favor of "Al-Wakeel News" in the following sources: "citizen" (52.4\%), "more than one source" (56.4\%), "refugee shelters \& camps" (49.1\%). The differences in favor of the "Turk Press" were in the following sources: "correspondent" (41.6\%) and "civil society institutions" (68.3\%). The differences in favor of "Ya-Sour" were referred to "police" as a source of $50.0 \%$. In contrast, there were no significant differences between the three websites in the sources of the following topics: "politicians", "social networks and social media" and "expert academic".

Table 4. Sources of the issues of the Syrian refugee crisis

\begin{tabular}{|l|l|c|c|c|c|c|c|c|c|c|c|}
\hline \multirow{2}{*}{ No } & Quantitative distribution & \multicolumn{2}{|c|}{ Al-Wakeel } & \multicolumn{2}{|c|}{ Ya-Sour } & \multicolumn{2}{|c|}{ Turk Press } & \multicolumn{2}{|c|}{ Total } & \multicolumn{2}{c|}{ K2 test } \\
\cline { 3 - 13 } & & $\mathrm{N}$ & $\%$ & $\mathrm{~N}$ & $\%$ & $\mathrm{~N}$ & $\%$ & $\mathrm{~N}$ & $\%$ & Value & Sig \\
\hline 1 & Correspondent & 99 & 32.1 & 81 & 26.3 & 128 & 41.6 & 308 & 100 & 11.0 & 0.01 \\
\hline 2 & Citizen & 88 & 52.4 & 49 & 29.2 & 31 & 18.5 & 168 & 100 & 30.3 & 0.01 \\
\hline 3 & Politicians & 79 & 29.8 & 88 & 33.2 & 98 & 37.0 & 265 & 100 & 2.1 & No Sig \\
\hline 4 & More than one source & 312 & 56.4 & 132 & 23.9 & 109 & 19.7 & 553 & 100 & 134.1 & 0.01 \\
\hline 5 & Refugee shelters and camps & 81 & 49.1 & 61 & 37.0 & 23 & 13.9 & 165 & 100 & 31.6 & 0.01 \\
\hline 6 & Social networks and social media & 89 & 37.4 & 83 & 34.9 & 66 & 27.7 & 238 & 100 & 3.6 & No Sig \\
\hline 7 & An expert academic & 11 & 42.3 & 7 & 26.9 & 8 & 30.8 & 26 & 100 & 1.0 & No Sig \\
\hline 8 & UN Refugee Affairs & 89 & 50.0 & 71 & 39.9 & 18 & 10.1 & 178 & 100 & 45.9 & 0.01 \\
\hline 9 & Police & 18 & 22.0 & 41 & 50.0 & 23 & 28.0 & 82 & 100 & 10.7 & 0.01 \\
\hline 10 & Civil society organizations & 9 & 15.0 & 10 & 16.7 & 41 & 68.3 & 60 & 100 & 33.1 & 0.01 \\
\hline
\end{tabular}

\subsection{Location of topics within news sites}

The results showed that the "sections" was the most frequently used site in the news websites as it was repeated (2213) times $(86.8 \%)$, followed by the site of the "home page" (215) times $(8.4 \%)$, and in third place came "special files" (122) times $(4.8 \%)$. The results based on each news site were consistent with the overall results where in all cases, it is shown that the "sections" site came first, followed by the "home" site, and the "special files" site.

The results of the study also show that there are statistically significant differences between the three websites in the refugee crisis presentation site. The differences were in favor of "Al-Wakeel News" in presenting the topics in the sections (35.7\%) and "Ya-Sour" in presenting topics within special files (45.9\%), while it is not clear that there are statistically significant differences between the three websites in the topic display in the "home page".

Table 5. Location of topics within news sites

\begin{tabular}{|c|l|c|c|c|c|c|c|c|c|c|c|}
\hline \multirow{2}{*}{ No } & Quantitative distribution & \multicolumn{2}{|c|}{ Al-Wakeel } & \multicolumn{2}{|c|}{ Ya-Sour } & \multicolumn{2}{|c|}{ Turk Press } & \multicolumn{2}{|c|}{ Total } & \multicolumn{3}{|c|}{ K2 test } \\
\cline { 3 - 13 } & & $\mathrm{N}$ & $\%$ & $\mathrm{~N}$ & $\%$ & $\mathrm{~N}$ & $\%$ & $\mathrm{~N}$ & $\%$ & Value & Sig \\
\hline 1 & Home page & 78 & 36.3 & 79 & 36.7 & 58 & 27.0 & 215 & 100 & 3.9 & No Sig \\
\hline 2 & Sections & 791 & 35.7 & 736 & 33.3 & 686 & 31.0 & 2213 & 100 & 7.5 & 0.01 \\
\hline 3 & Special files & 41 & 33.6 & 56 & 45.9 & 25 & 20.5 & 122 & 100 & 11.8 & 0.01 \\
\hline
\end{tabular}


5.6 Focal figures in published material on the Syrian refugee crisis

Answering the research second question: What are the characteristics of the press coverage, what is the characterization of the Syrian refugee, and what are the expected risks or proposed solutions to the Syrian refugee crisis?), the results show that the most focal figures in the published articles on the Syrian refugee crisis are the "political figures", which were repeated (341) times (28.7\%), followed by "international organizations" ( 226) times (19.0\%), then "international personalities" (200 times) $(16.8 \%)$.

The results of the "Al-Wakeel News" and "Ya-Sour" websites were consistent with the general results of the focal figures. The results of the "Turk Press" website were slightly different as "local organizations" came second (78) times $(21.6 \%)$, followed in the third place by "international organizations and activists" (51) times $(14.1 \%)$.

While the results of the "Al-Wakeel News" and "Ya-Sour" websites were consistent with the general results of the focal figures, the results of the "Turk Press" website were slightly different. "Local organizations" came second and were repeated (78) times (21.6\%), and "international organizations and activists" were repeated (51) times $(14.1 \%)$ and came in the third place. The results of the study in the same context, showed differences of statistical significance between the three websites in the focal figures in the published articles on refugee issues, and the differences were in favor of "Al Wakeel News" website in dealing with "international figures" (49.0\%), "unofficial figures" (45.9\%), and in favor of "Ya-Sour" website (43.4\%) in dealing with "international organizations", and in favor of "Turk Press" website (54.5\%) in dealing with "local organizations". The results show that there are no statistically significant differences between the three websites in dealing with "political figures" and "activists".

Table 6. Focal figures in published material on the Syrian refugee crisis

\begin{tabular}{|l|l|c|c|c|c|c|c|c|c|c|c|}
\hline \multirow{2}{*}{ No } & \multirow{2}{*}{ Quantitative distribution } & \multicolumn{2}{|c|}{ Al-Wakeel } & \multicolumn{2}{c|}{ Ya-Sour } & \multicolumn{2}{c|}{ Turk Press } & \multicolumn{2}{|c|}{ Total } & \multicolumn{3}{c|}{ K2 test } \\
\cline { 3 - 13 } & & $\mathrm{N}$ & $\%$ & $\mathrm{~N}$ & $\%$ & $\mathrm{~N}$ & $\%$ & $\mathrm{~N}$ & $\%$ & Value & Sig \\
\hline 1 & Political figures & 121 & 35.5 & 109 & 32.0 & 111 & 32.6 & 341 & 100 & 0.7 & No Sig \\
\hline 2 & International personalities & 98 & 49.0 & 71 & 35.5 & 31 & 15.5 & 200 & 100 & 34.1 & 0.01 \\
\hline 3 & Activists & 39 & 26.5 & 57 & 38.8 & 51 & 34.7 & 147 & 100 & 3.4 & No Sig \\
\hline 4 & Informal figures & 61 & 45.9 & 33 & 24.8 & 39 & 29.3 & 133 & 100 & 9.8 & 0.01 \\
\hline 5 & Local organizations & 24 & 16.8 & 41 & 28.7 & 78 & 54.5 & 143 & 100 & 32.0 & 0.01 \\
\hline 6 & International organizations & 77 & 34.1 & 98 & 43.4 & 51 & 22.6 & 226 & 100 & 14.7 & 0.01 \\
\hline
\end{tabular}

\subsection{The qualities used by news websites for refugees}

The most prominent feature used by the news websites for the Syrian refugees is the word "refugee", where it was repeated (1046) times (49.4\%), followed by the word "illegal" (440) times (20.8\%), and in the third place the word "displaced" which was repeated (382) times (18.0\%). The ranking of the attributes according to the news websites is almost consistent with the general results.

It is clear from the results of the study that there are statistically significant differences between the three websites in the characteristics that the news sites use for the refugees. The differences were in favor of the "AlWakeel News" in the use of "displaced" (49.7\%), and "Ya-Sour" in the use of "refugee" (51.9\%) and "illegal" (52.5\%), whereas "Turk Press" used "temporary resident" (42.1\%). The results show no statistically significant differences between the three websites in the use of the word "brotherhood".

Table 7. The qualities used by news websites for refugees

\begin{tabular}{|l|l|c|c|c|c|c|c|c|c|c|c|}
\hline \multirow{2}{*}{ No } & Quantitative distribution & \multicolumn{2}{|c|}{ Al-Wakeel } & \multicolumn{2}{c|}{ Ya-Sour } & \multicolumn{2}{c|}{ Turk Press } & \multicolumn{2}{c|}{ Total } & \multicolumn{3}{c|}{ K2 test } \\
\cline { 3 - 13 } & & $\mathrm{N}$ & $\%$ & $\mathrm{~N}$ & $\%$ & $\mathrm{~N}$ & $\%$ & $\mathrm{~N}$ & $\%$ & Value & Sig \\
\hline 1 & Refugee & 231 & 22.1 & 543 & 51.9 & 272 & 26.0 & 1046 & 100 & 164.9 & 0.01 \\
\hline 2 & Displaced & 190 & 49.7 & 103 & 27.0 & 89 & 23.3 & 382 & 100 & 47.0 & 0.01 \\
\hline 3 & Illegal & 107 & 24.3 & 231 & 52.5 & 102 & 23.2 & 440 & 100 & 72.8 & 0.01 \\
\hline 4 & Temporary resident & 54 & 25.8 & 67 & 32.1 & 88 & 42.1 & 209 & 100 & 8.5 & 0.01 \\
\hline 5 & Brotherhood & 13 & 31.0 & 15 & 35.7 & 14 & 33.3 & 42 & 100 & 0.1 & No Sig \\
\hline
\end{tabular}

\subsection{The expected dangers of refugees presented by news websites}

It is clear from the results of the study that the most expected risk of Syrian refugees presented by the news websites in the study is "security risk", which was repeated (401) times (40.3\%), followed by "economic risks" 398 times (40.0\%) ), and "demographic risks" came third (107) times (10.8\%). The results of the study also indicate that there are other risks expected for Syrian refugees: "religious / cultural risks" repeated through the "Ya-Sour" (37) times (10\%) and "Turk Press" (22 times) (9.2\%). This is an important indicator because of the fear of the impact of cultural and religious differences on the population of the three countries neighboring Syria (Lebanon, Turkey, Jordan), i.e the study sample.

It is also clear from the results of the study that there are statistically significant differences between the 
three websites in presenting the expected risks of refugees. The differences were in favor of "Al-Wakeel News" in the presentation of "economic risks" (43.0\%) and "demographic risks" (48.6\%). And in favor of the "Ya-Sour" in the "security risk" (42.4\%). There are no statistically significant differences between the three websites in the presentation of "religious / cultural risks".

Table 8 . The expected dangers of refugees presented by news websites

\begin{tabular}{|l|l|c|c|c|c|c|c|c|c|c|c|}
\hline \multirow{2}{*}{ No } & \multirow{2}{*}{ Quantitative distribution } & \multicolumn{2}{|c|}{ Al-Wakeel } & \multicolumn{2}{c|}{ Ya-Sour } & \multicolumn{2}{c|}{ Turk Press } & \multicolumn{2}{c|}{ Total } & \multicolumn{3}{|c|}{ K2 test } \\
\cline { 3 - 12 } & & $\mathrm{N}$ & $\%$ & $\mathrm{~N}$ & $\%$ & $\mathrm{~N}$ & $\%$ & $\mathrm{~N}$ & $\%$ & Value & Sig \\
\hline 1 & Security risks & 133 & 33.2 & 170 & 42.4 & 98 & 24.4 & 401 & 100 & 19.4 & 0.01 \\
\hline 2 & Economic risk & 171 & 43.0 & 128 & 32.2 & 99 & 24.9 & 398 & 100 & 19.8 & 0.01 \\
\hline 3 & Demographic threat & 52 & 48.6 & 34 & 31.8 & 21 & 19.6 & 107 & 100 & 13.6 & 0.01 \\
\hline 4 & Religious / cultural risks & 30 & 33.7 & 37 & 41.6 & 22 & 24.7 & 89 & 100 & 3.8 & No Sig \\
\hline
\end{tabular}

\subsection{Proposed solutions to the refugee issue presented by news websites}

The results of the study show that the most suggested solutions to the Syrian refugee crisis, focused on by the news websites were "support and increases in donations and international aid", which were repeated 217 times, $(28.8 \%)$, followed in second place by "safe areas in Syria" $(25.6 \%)$, then in the third place came the proposed solution "absorbed until the end of the war" (179) times (23.7\%).

The results of the study show that there are statistically significant differences between the three websites in presenting the proposed solutions to the refugee issue. The differences were in favor of "Ya-Sour" in presenting the following solutions: (46.6\%) proposed "sending them back to the safe areas in Syria", $(42.3 \%)$, proposed "support and increases in donations and international aid" (40.1\%). The difference in favor of the "Turk Press" was "to focus on support and increases in grants and international aid" by (40.1\%). The results showed no statistically significant differences between the three websites in the focus on "resettlement / integration".

Table 9. Proposed solutions to the refugee issue presented by news websites

\begin{tabular}{|l|l|c|c|c|c|c|c|c|c|c|c|}
\hline No & Quantitative distribution & \multicolumn{2}{|c|}{$\begin{array}{l}\text { Al- } \\
\text { Wakeel }\end{array}$} & \multicolumn{2}{|c|}{$\begin{array}{c}\text { Ya- } \\
\text { Sour }\end{array}$} & \multicolumn{2}{c|}{$\begin{array}{c}\text { Turk } \\
\text { Press }\end{array}$} & \multicolumn{2}{|c|}{ Total } & \multicolumn{2}{c|}{ K2 test } \\
\cline { 3 - 13 } & & $\mathrm{N}$ & $\%$ & $\mathrm{~N}$ & $\%$ & $\mathrm{~N}$ & $\%$ & $\mathrm{~N}$ & $\%$ & Value & Sig \\
\hline 1 & Resettlement/ integration & 1 & 50.0 & 0 & 0.0 & 1 & 50.0 & 2 & 100 & 1.0 & $\begin{array}{c}\text { No } \\
\text { Sig }\end{array}$ \\
\hline 2 & Absorbed until the end of the war & 75 & 41.9 & 26 & 14.5 & 78 & 43.6 & 179 & 100 & 28.6 & 0.01 \\
\hline 3 & $\begin{array}{l}\text { Sending them back to the safe areas of } \\
\text { Syria }\end{array}$ & 80 & 41.5 & 90 & 46.6 & 23 & 11.9 & 193 & 100 & 40.6 & 0.01 \\
\hline 4 & Create safe areas & 66 & 40.5 & 69 & 42.3 & 28 & 17.2 & 163 & 100 & 19.2 & 0.01 \\
\hline 5 & $\begin{array}{l}\text { Support and increases in donations and } \\
\text { international aid }\end{array}$ & 51 & 23.5 & 87 & 40.1 & 79 & 36.4 & 217 & 100 & 9.9 & 0.01 \\
\hline
\end{tabular}

In response to the third research question: what are the content trends, what are the persuasion methods and persuasive methods used in press coverage?, the following results are obtained.

\subsection{Content Trends on the Syrian Refugee Crisis}

The results of the study show that the most Syrian refugee cases focused on by the news websites were "the impact of refugees on the price rise of commodities" (299) times $(9.9 \%)$, followed by the "difficult conditions experienced by the refugees" (288) (9.5\%), then "Refugee Impact on the Labor Market" (284) times (9.4\%).

As for the results according to the trend, it is clear that the most prominent issues of Syrian refugees that the news websites dealt with favorably are "the impact of refugees on the demographic nature", which was repeated (213) times $(11.4 \%)$, followed by "difficult conditions experienced by refugees" (107) times $(10.6 \%)$, and in the third place came "donations and international aid to refugees" (186) times $(10.0 \%)$. The results show that the most prominent Syrian refugee issues dealt with neutrally by news websites are "on the labor market "which was repeated (62) times (13.0\%), followed in the second place by "the spread of crimes due to refugees" (52) times $(10.9 \%)$, and in the third place came "international aid and donations to refugees" (43) times $(9.0 \%)$. "The impact of refugees on the price rise of commodities" was repeated 115 times by $16.5 \%$, followed by "the impact of refugees on the labor market ( 69) times (9.9\%) and third came "the spread of crimes due to refugees" (61) times $(8.8 \%)$. 
Table 10. Content Trends on the Syrian Refugee Crisis

\begin{tabular}{|c|c|c|c|c|c|c|c|c|c|c|c|}
\hline \multirow[t]{2}{*}{ No } & \multirow[t]{2}{*}{ Quantitative distribution } & \multicolumn{2}{|c|}{$\begin{array}{c}\text { Al- } \\
\text { Wakeel }\end{array}$} & \multicolumn{2}{|c|}{$\begin{array}{l}\text { Ya- } \\
\text { Sour }\end{array}$} & \multicolumn{2}{|c|}{$\begin{array}{l}\text { Turk } \\
\text { Press }\end{array}$} & \multicolumn{2}{|c|}{ Total } & \multicolumn{2}{|c|}{$\mathrm{K} 2$ test } \\
\hline & & $\mathrm{N}$ & $\%$ & $\mathrm{~N}$ & $\%$ & $\mathrm{~N}$ & $\%$ & $\mathrm{~N}$ & $\%$ & Value & Sig \\
\hline 1 & The spread of crimes due to refugees & 151 & 57.2 & 52 & 5.4 & 61 & 23.1 & 264 & 100 & 68.1 & 0.01 \\
\hline 2 & $\begin{array}{l}\text { Weak services in refugee camps and } \\
\text { shelters }\end{array}$ & 156 & 60.5 & 42 & 4.4 & 60 & 23.3 & 258 & 100 & 87.4 & 0.01 \\
\hline 3 & The difficult conditions of the refugees & 197 & 68.4 & 36 & 3.8 & 55 & 19.1 & 288 & 100 & 161.3 & 0.01 \\
\hline 4 & $\begin{array}{l}\text { The impact of refugees on price rise of } \\
\text { commodities }\end{array}$ & 163 & 54.5 & 21 & 2.2 & 115 & 38.5 & 299 & 100 & 104.7 & 0.01 \\
\hline 5 & donations and international aid to refugees & 186 & 69.7 & 43 & 4.5 & 38 & 14.2 & 267 & 100 & 158.7 & 0.01 \\
\hline 6 & Impact of refugees on the labor market & 153 & 53.9 & 62 & 6.5 & 69 & 24.3 & 284 & 100 & 54.2 & 0.01 \\
\hline 7 & $\begin{array}{l}\text { refugees on education, schools } \\
\text { ities }\end{array}$ & 79 & 53.7 & 20 & 2.1 & 48 & 32.7 & 147 & 100 & 35.6 & 0.01 \\
\hline 8 & $\begin{array}{l}\text { The impact of refugees on rising real estate } \\
\text { prices and rents }\end{array}$ & 121 & 62.7 & 42 & 4.4 & 30 & 15.5 & 193 & 100 & 76.0 & 0.01 \\
\hline 9 & $\begin{array}{l}\text { Impact of terrorism and organized crime } \\
\text { issues }\end{array}$ & 43 & 31.6 & 42 & 4.4 & 51 & 37.5 & 136 & 100 & 1.1 & $\begin{array}{l}\text { No } \\
\text { Sig }\end{array}$ \\
\hline 10 & $\begin{array}{l}\text { The impact of refugees on the social } \\
\text { situation }\end{array}$ & 130 & 63.7 & 30 & 3.1 & 44 & 21.6 & 204 & 100 & 86.2 & 0.01 \\
\hline 11 & $\begin{array}{l}\text { Influence of refugees on the demographic } \\
\text { change }\end{array}$ & 213 & 76.9 & 29 & 3.0 & 35 & 12.6 & 277 & 100 & 236.7 & 0.01 \\
\hline 12 & $\begin{array}{l}\text { Influence of refugees on the religious } \\
\text { component }\end{array}$ & 132 & 63.8 & 17 & 1.8 & 58 & 28.0 & 207 & 100 & 98.5 & 0.01 \\
\hline 13 & The impact of refugees on public security & 139 & 65.9 & 40 & 4.2 & 32 & 15.2 & 211 & 100 & 101.0 & 0.01 \\
\hline
\end{tabular}

\subsection{Methods of persuasion within the material published in the coverage}

It is clear from the results of the study that the most persuasive methods used in the news websites to present the issues of Syrian refugees are "the use of rhetorical and descriptive slogans" which was repeated (596) times $(25.7 \%)$, followed by "one sided view" in the second place (457) (19.7\%), and in the third place came "exaggeration and intimidation" (444) times (19.1\%).

The results of the study also show that the "Al-Wakeel News" website appears to be less neutral in the use of persuasion methods: "exaggeration and intimidation" was used first and repeated 246 times (27.0\%), followed by "one sided view" (229) time (25.2\%). "Turk Press" seems to be more neutral as it used "descriptive and rhetorical slogans" (26.9\%), followed by "multiple views" (177 times) ( $25.6 \%$ ), and in the third place came "quoting figures and statistics" (129) times (18.7\%).

In a related context, the results of the study showed that there were statistically significant differences between the three websites in persuasion methods. The differences were in favor of the "Al-Wakeel" website in "one sided view" (50.1\%) and "exaggeration and intimidation" (55.4\%), followed by "Ya-Sour" in "citation of figures and statistics" (40.6\%) and then "Turk Press" (45.2\%). There are no statistically significant differences between the three websites in the use of rhetorical and descriptive slogans.

Table 11. Methods of persuasion within the material published in the coverage

\begin{tabular}{|c|l|c|c|c|c|c|c|c|c|c|c|}
\hline \multirow{2}{*}{ No } & Quantitative distribution & \multicolumn{2}{|c|}{ Al-Wakeel } & \multicolumn{2}{|c|}{ Ya-Sour } & \multicolumn{2}{c|}{ Turk Press } & \multicolumn{2}{|c|}{ Total } & \multicolumn{2}{c|}{ K2 test } \\
\cline { 3 - 12 } & & $\mathrm{N}$ & $\%$ & $\mathrm{~N}$ & $\%$ & $\mathrm{~N}$ & $\%$ & $\mathrm{~N}$ & $\%$ & Value & Sig \\
\hline 1 & one sided view & 229 & 50.1 & 108 & 23.6 & 120 & 26.3 & 457 & 100 & 58.4 & 0.01 \\
\hline 2 & Exaggeration and intimidation & 246 & 55.4 & 119 & 26.8 & 79 & 17.8 & 444 & 100 & 102.7 & 0.01 \\
\hline 3 & multiple views & 105 & 26.8 & 110 & 28.1 & 177 & 45.2 & 392 & 100 & 24.7 & 0.01 \\
\hline 4 & Citation of numbers and statistics & 129 & 29.7 & 176 & 40.6 & 129 & 29.7 & 434 & 100 & 10.2 & 0.01 \\
\hline 5 & Use of rhetorical and descriptive slogans & 201 & 33.7 & 209 & 35.1 & 186 & 31.2 & 596 & 100 & 1.4 & No Sig \\
\hline
\end{tabular}

\subsection{The persuasive methods used to present refugee issues}

It is clear from the results of the study that the most persuasive methods used to highlight the Syrian refugees' issues in the news websites are "intimidation" which was repeated (959) times (47.2\%), followed by "violent abuse" (750) times (36.9\%), and then "sympathetic persuasion" and (201) times (9.9\%).

In the same context, the "Al-Wakeel News" website appears to be more frequently used for "violent abuse" (437) times (48.0\%) and "disguised persuasions" (389) times (42.7\%). In the same direction, "Ya-Sour" website was the most frequently used for "intimidation", which was repeated 499 times $57.3 \%$, followed by "violent abuse" (301) times (34.6\%), whereas Al-Wakeel's "Sympathetic persuasions" did not exceed (5.8\%), and "Ya- 
our" (4.6\%). On the other hand, "sympathetic persuasions" were more frequent in the "Turk Press" (108) times $(42.9 \%)$.

The results of the study showed that there were statistically significant differences between the three websites in the persuasion methods used to present the refugee crisis. The differences were in favor of the "AlWakeel News" website in the use of "violent abuse" (58.3\%), "Ya-Sour" in the use of "intimidation" (52.0\%), and "Turk Press" in the use of "mental persuasion" (49.6\%) and "sympathetic persuasion" (53.7\%).

Table 12. The persuasive methods used to present refugee issues

\begin{tabular}{|l|l|c|c|c|c|c|c|c|c|c|c|}
\hline \multirow{2}{*}{ No } & Quantitative distribution & \multicolumn{2}{|c|}{ Al-Wakeel } & \multicolumn{2}{c|}{ Ya-Sour } & \multicolumn{2}{c|}{ Turk Press } & \multicolumn{2}{|c|}{ Total } & \multicolumn{3}{|c|}{ K2 test } \\
\cline { 3 - 12 } & & $\mathrm{N}$ & $\%$ & $\mathrm{~N}$ & $\%$ & $\mathrm{~N}$ & $\%$ & $\mathrm{~N}$ & $\%$ & Value & Sig \\
\hline 1 & Mental persuasion & 31 & 25.2 & 31 & 25.2 & 61 & 49.6 & 123 & 100 & 14.6 & 0.01 \\
\hline 2 & Sympathetic persuasion & 53 & 26.4 & 40 & 19.9 & 108 & 53.7 & 201 & 100 & 38.9 & 0.01 \\
\hline 3 & Intimidation & 389 & 40.6 & 499 & 52.0 & 71 & 7.4 & 959 & 100 & 309.1 & 0.01 \\
\hline 4 & Violent abuse & 437 & 58.3 & 301 & 40.1 & 12 & 1.6 & 750 & 100 & 376.9 & 0.01 \\
\hline
\end{tabular}

\section{Discussion and Conclusion}

The results of a study covering the neighboring countries' press coverage of the Syrian refugee crisis through Lebanese "Ya-Sour ", Jordanian "Al-Wakeel News" and Turkish "Turk Press"

Intersected with the results of previous studies. The most important topics related to the refugee crisis discussed are "security", "economic" and "political" issues (Efe, 2019). It came in two basic reporting styles: News stories and The News Report (Mhirat, 2014, Al-Mazahrah, 2016). It also used structural elements that included primarily "objectivity" and "personality" and "links and references". The terms "refugee", "illegitimate" and "displaced" have been dominant in the press coverage in their description of the Syrian refugee (Hoyer, 2016).

The "political figures" were among the main figures in the published articles, followed by "international organizations" and "international figures". The coverage focused on a number of potential risks to the Syrian refugee crisis, notably "security risks", "economic risks" and "demographic risks" (Efe, 2019). The proposed solutions focused on "support and increases in donations and international aid", "Returning them to safe areas in Syria" and "absorbing them until the end of the war".

As for persuasion methods used in press coverage, the most important methods were "using rhetorical and descriptive slogans" and "one sided view" as well as "exaggeration and intimidation". As for persuasion methods used in the press coverage, "intimidation" and "violent abuse" were the most frequently used in the news websites of the study sample, while the results showed that "Turk Press" appears to be more neutral and sympathetic to the Syrian refugee crisis, compared to the "Al-Wakeel" and "Ya-Sour" at the level of persuasion methods used in press coverage.

\section{References}

Alexa (2019). Top Sites in Jordan [Online] Available at: https://www.alexa.com/topsites/countries/JO [Accessed 12 March 12 2018].

Alexa (2019). Top Sites in Lebanon [Online] Available at: https://www.alexa.com/topsites/countries/LB [Accessed 12 March 2018].

Alexa (2019). Turkpress.co [Online] Available at: https://www.alexa.com/siteinfo/turkpress.co [Accessed 12 March 2018].

Alhayek, K. (2014). Double Marginalization: The Invisibility of Syrian Refugee Women's Perspectives in Mainstream Online Activism and Global Media. Feminist Media Studies, 14(4), 696-700, DOI: $10.1080 / 14680777.2014 .935205$

Al-Mazahrah, M. (2016). The Jordanian Media Coverage of the Syrian Refugees Crisis in Jordan: Analytical Study of Daily Newspapers (Al-Rai, Al-Dustor, and Al-arab Alyoum). Journal of Middle East Media, 10(1), $1-20$.

Berry, M. et al. (2015). Press Coverage of the Refugee and Migrant Crisis in the EU: A Content Analysis of Five European Countries. Report prepared for the United Nations High Commission for Refugees. Cardiff School of Journalism, Media and Cultural Studies. [Online] Available at: https://www.unhcr.org/56bb369c9.pdf [Accessed 15 December 2018].

Barzilai-Nahon, K. (2009). Gatekeeping: A critical review. Annual Review of Information Science and Technology. 43, 1-79, DOI:10.1002/aris.2009.1440430117

Efe, I. (2019). A corpus-driven analysis of representations of Syrian asylum seekers in the Turk Press 2011-2016. Discourse \& Communication. 13(1) 48-67.

Farej, M. N. et al. (2014). Media Coverage of Recent Crises in Middle East: Daily Jordanian Press Coverage of Events in Syria 2011-2013. International Journal of Academic Research in Business and Social Sciences. 4(4) 99-107. 
Fotopoulos, S. \& Kaimaklioti, M. (2016). Media discourse on the refugee crisis: on what have the Greek, German and British press focused? European View, 15, 265-279, DOI 10.1007/s12290-016-0407-5

Grawitz, M. (1993). Méthodes des sciences sociales, Paris : Dalloz.

Greenwood, K., \& Thomson, T. (2019). Framing the migration: A study of news photographs showing people fleeing war and persecution. International Communication Gazette. [Online] Available: https://doi.org/10.1177/1748048519833515 [Accessed 15 December 2018].

Holsti, O.R. (1969). Content Analysis for the Social Sciences and Humanities. Reading, MA: Addison-Wesley.

Hoyer, A. (2016). Spanish News Framing of the Syrian Refugee Crisis. WWU Honors Program Senior Projects. 26. [Online] Available at: https://cedar.wwu.edu/wwu honors/26 [Accessed 12 January 2018].

Maharat Foundation, (2016). Media Coverage of Refugees Issues: Lebanon, Jordan, Egypt, Morocco. [Online] Available at: http://www.maharatfoundation.org/publications/studies/refugee [Accessed 27 January 2018].

McCombs, M. (1972). The Agenda-Setting Role of the Mass Media in the Shaping of Public Opinion. [Online] Available at: https://www.researchgate.net/publication/237394610 The AgendaSetting_Role_of_the_Mass_Media_in_the_Shaping_of_Public_Opinion [Accessed 14 January 2018].

Mhirat, A. M. (2014). TV News Coverage of Issues Pertaining to Syrian Refugees from the Stand Point of News Makers. Middle East University.

Ramasubramanian, S. \& Miles, C. (2018). Framing the Syrian Refugee Crisis: A Comparative Analysis of Arabic and English News Sources. International Journal of Communication 12(2018), 4488-4506.

Venir, A. (2015). UK Media Representation of Syrian Refugees: A Focus on the Press. [Online] Available at: https://www.academia.edu/9283960/UK_Media_Representation_of_Syrian_Refugees_A_Focus_on_the_Pr ess [Accessed 7 January 2019)

Yaylaci, F. G. et al. (2015). Perceptions and newspaper coverage of Syrian refugees in Turkey. Migration Letters, 12(3), 238- 250.

Zaaroor, M. A, (2018). Factors governing the Syrian refugee's crisis in the Lebanese press: An analytical study of Alakhbar, Annahar, As-Safir and Almustaqbal newspapers. 